NBER WORKING PAPER SERIES

\title{
GENERATIONAL ACCOUNTING IN GENERAL EQUILIBRIUM
}

\author{
Hans Fehr \\ Laurence J. Kotlikoff
}

Working Paper No. 5090

\author{
NATIONAL BUREAU OF ECONOMIC RESEARCH \\ 1050 Massachusetts Avenue \\ Cambridge, MA 02138 \\ April 1995
}

Parts of this paper were written when Hans Fehr was a Visiting Scholar at the Department of Economics, Boston University. His fellowship from the German Research Foundation (grant no. Fe 377/1-1) is gratefully acknowledged as is the research support extended to Laurence Kotlikoff by The World Bank, Mr. Charles Benenson, and Mr. Lawrence Benenson. We thank Alan Auerbach and Jagadeesh Gokhale for helpful comments. This paper is part of NBER's research program in Public Economics. Any opinions expressed are those of the authors and not those of the National Bureau of Economic Research.

(C) 1995 by Hans Fehr and Laurence J. Kotlikoff. All rights reserved. Short sections of text, not to exceed two paragraphs, may be quoted without explicit permission provided that full credit, including $\odot$ notice, is given to the source. 
NBER Working Paper \#5090

April 1995

\title{
GENERATIONAL ACCOUNTING IN GENERAL EQUILIBRIUM
}

\begin{abstract}
This paper shows how changes in generational accounts relate to the generational incidence of fiscal policy. To illustrate the relationship, it uses the Auerbach-Kotlikoff Dynamic Life-Cycle Simulation Model to compare policy-induced changes in generational accounts with actual changes in generations' utilities. The paper considers a wide range of policies in closed and small open economies as well as economies with and without capital adjustment costs.

In general, changes in generational accounts appear to provide fairly good approximations to generations' actual changes in utilities. The approximations are better for living generations. They are worse for policies that involve significant changes in the degree of tax progressivity and for economies with sizable capital-adjustment costs.

Finally, generational accounting needs to be adjusted in the case of small open economies to take into account the fact that the incidence of corporate taxation is on labor. The method of adjustment is simply to allocate changes in corporate tax revenues to generations in proportion to their changes in labor supply.
\end{abstract}

Hans Fehr

Universitat Tübingen

Mohlstrasse 36

D-7400 Tübingen

GERMANY
Laurence J. Kotlikoff

Department of Economics

Boston University

270 Bay State Road

Boston, MA 02215

and NBER 


\section{Introduction}

Generational accounting is a relatively new tool of long-term fiscal analysis. ${ }^{1}$ It is based on the government's intertemporal budget constraint which requires that the government's bills be paid by current or future generations. These bills refer to the present value of the government's projected future spending plus the current value of its official net debt. The payments of current and future generations are also measured in present value and equal the projected value of their future net tax payments (taxes paid less transfer payments received).

Generational accounts measure, in present value, the projected future net tax payments of current and future generations. The difference between the government's bills and the collective generational accounts of current generations determines the present value of the net tax burden facing future generations. Comparisons of the generational accounts of current and future generations indicates the extent to which fiscal policy is, generationally speaking, out of balance. Generational accounting also reveals changes in the generational distribution of fiscal burdens arising from policy reforms. Since generational accounting considers the taxes paid to, and transfers received from, all levels of government (federal, state, and local), it provides a comprehensive picture of the fiscal treatment of different generations.

Although it is less than five years old, generational accounting has made significant inroads in fiscal analysis, both in the U.S. and abroad. It has been included in the Budget of the United States Government and is being used by the governments of Norway, Italy, Japan, and New Zealand. The IMF is preparing

1 See Auerbach, Gokhale, and Kotlikoff (1991, 1992, and 1994) and Kotlikoff (1992 and 1993). 
generational accounts for Sweden, the World Bank is preparing them for Thailand, and academic economists have prepared or are preparing them for Germany, Canada, and Australia. ${ }^{2}$

Given its growing use, it is important to understand the limitations as well as advantages of generational accounting. One concern about generational accounting is the accuracy of its implicit incidence assumptions. Generational accounting assumes that taxes on labor income are paid (in the economic sense) by workers, that taxes on capital income are paid by suppliers of capital, and that sales, excise, and value added taxes are paid by consumers. It also assumes that recipients (in the economic sense) of transfers, such as social security benefits, are those individuals who receive these payments. Given its incidence assumptions, generational accounting simply adds together the taxes paid by members of particular generations when they work, receive capital income, and purchase commodities, and subtracts from the total tax payment the total amount of transfer payments received.

Another way of stating these incidence assumptions is that generational accounting takes pre-tax factor returns as given; i.e., it ignores potential policyinduced changes in factor returns which can alter the ultimate incidence of fiscal policies. In addition to this shortcoming, generational accounting may not accurately reflect those changes in generations' utility levels associated with their efforts to avoid fiscal burdens, such as consuming less of taxed goods.

In order to set these shortcomings against the advantages of the existing method of generational accounting -- namely its simplicity and clarity --, one needs

2 See U.S. Office of Management and Budget $(1992,1993$, 1994), Franco, et. al. (1994), Auerbach, et. al. (1993), Boll, et. al. (1994), and Gokhale, Raffelhuschen, and Walliser (1994). 
to study, as this paper does, their magnitude. This paper uses the AuerbachKotlikoff (1987) dynamic life-cycle model (henceforth, the AK Modell to study the degree to which generational accounting captures the changes in generations' utilities resulting from particular policy reforms. It does so by simulating a range of alternative policies and comparing the resulting changes in generations' utilities with the associated changes in generational accounts. Since the AK Model can be run as either a closed or a small open economy, the paper also sheds light on how an economy's openness may affect the accuracy of its generational accounting.

In our simulations of closed economies with no capital adjustment costs, generational accounting does quite well in capturing the sign pattern and magnitudes of generations' utility-changes. This is not entirely surprising. In closed economies with no adjustment costs, factor returns are determined by the capital-labor ratio. Since the capital stock is fixed in the short run and since labor supply is fairly inelastic in the AK Model, the capital-labor ratio changes gradually in response to policy changes. ${ }^{3}$ Consequently, factor returns also change gradually. In addition, the income effects from the initial direct changes in tax burdens play the key role in altering household saving and labor supply, which, in turn, determine the changes in the capital-labor ratio and factor returns. Hence, the changes in factor returns are second-round or feedback effects from the policy change. Since the model is stable, these second-round changes in factor returns are smaller in magnitude than the first-round effects which are, to a considerable extent, captured by changes in generational accounts. Moreover, although policy-

3 The utility function of the AK Model is calibrated based on empirical studies of U.S. labor supply and consumption. 
induced changes in behavior are non trivial, they are nonetheless a relatively small factor in generations' utility changes.

Adding capital-adjustment costs weakens the link between the return to capital and the capital-labor ratio. This return is no longer determined simply by capital's marginal product (which depends on the capital-labor ratio), but also by revaluations of the stock market (the market price of capital). When capitaladjustment costs are large, policy changes can produce sharp changes in stock market valuations that alter generations' welfare, but are not captured in generational accounting. This finding -- that generational accounting misses a portion of generations' changes in utilities in the presence of sizable adjustment costs -- needs, however, to be considered in light of the limited empirical evidence in support of adjustment costs (Cutler 1988).

Running the AK Model as a small open economy is another way to generate significant and immediate changes in factor returns. The reason is that an economy's capital-labor ratio can change instantaneously in response to capital inflows and outflows. Our simulations of corporate tax changes in small open economies suggests the need to modify generational accounting in such economies by allocating changes in corporate capital income taxes to generations in proportion to their labor income. The reason is that an increase in the corporate income tax rate in a small open economy will produce an immediate capital outflow, thereby lowering the marginal product of labor and the wage; i.e., the corporate tax will be immediately shifted to workers.

The paper continues in Section II by first considering the analogy between generational accounting and tax incidence analysis in a supply and demand diagram and then using a simple two-period life-cycle model to illustrate how one 
can decompose policy-induced changes in generations' utilities into three components: 1) the change in their generational accounts, 2) the change in their factor income, and 3) the change in their economic behavior, which we refer as their net tax avoidance. Section III reports our simulation results using the 55period AK Model for closed as well as small open economies. In the case of the small open economy, we consider both corporate and personal taxation of capital income. Section IV summarizes our findings and draws conclusions.

\section{Fiscal Reforms and Changes in Generations' Utilities}

\section{Generational Accounting -- The Analogy to Incidence in a Simple Static Model}

Before considering the relationship between changes in generational accounts and changes in utility in a dynamic model, it may be helpful to draw the analogy between generational accounting and tax incidence in a simple static setting. Figure 1 considers a tax on labor. The demand for labor is governed by the demand curve $D$, and the supply of labor is governed by the uncompensated supply curve S. The area BCEF indicates the change in worker's surplus, i.e., the change in utility that workers experience from the tax. Generational accounting, in effect, approximates the change in workers' surplus by the change in tax revenue, ACED. In so doing, it fails to subtract from the change in tax revenues the taxinduced increase in workers' factor income, ABFD, or add to the change in tax revenues the change in tax avoidance, DEF. ${ }^{4}$ Making both of these adjustments produces the exact change in workers' utility.

4 DEF partly reflects the excess burden from the tax. In particular, if one compensates workers for the changes in their nominal tax payments and their factor incomes, one would, in effect, replace the uncompensated supply curve with the compensated supply curve and end up with a triangular area equalling the excess burden of the tax. The closer in value are the compensated and uncompensated labor supply elasticities (i.e., the smaller in absolute value is the income elasticity), the greater the degree to which the change in tax avoidance will reflect the excess burden of the tax. 
Clearly, how well the change in tax revenues approximates the change in workers' surplus depends on the relative values of supply and demand elasticities. If supply is perfectly inelastic, the change in tax revenues exactly equals the change in workers' surplus. This also occurs if the change in workers' pre-tax income exactly equals the change in tax avoidance. At the other extreme, if demand is perfectly inelastic, workers' surplus is unchanged, and the change in tax revenues is a very bad measure of workers' utility change.

\section{Incidence in a Simple Two-Period Model}

Next consider fiscal incidence in a simple two-period life-cycle model. Each generation has the same size population which we normalize to 1 , and each agent has 1 unit of time each period to spend working or enjoying leisure. The utility function of a generation born at time s depends on consumption and leisure when young and old, i.e.,

$$
U_{s}=u\left(c_{y s}, c_{o s+1}, l_{y s}, l_{o s+1}\right),
$$

where $c$ indexes consumption, $l$ indexes leisure, $y$ indexes young, and $o$ indexes old.

Now suppose a change in policy occurs at time t. To understand its welfare effects, we need to examine the changes in utility of the old at time $t$, the young at time $t$, and all subsequent generations. We start by considering the old at time $t$, whose consumption is constrained by

$$
c_{o t}-k_{t}\left(1+r_{t}\right)+w_{t}\left(1-l_{o t}\right)-T_{o t} \text {, }
$$


where $k t$ is the capital owned by the old at time $t$, Tot is the remaining net tax payment of the old at time $t$ (their generational account), wt is the wage per unit of labor supply, and $r t$ is the time-t return per unit of capital. ${ }^{5}$ The generational account of the old at time t, Tot, as well as those of other generations, includes all net tax payments, whether or not they are distortionary.

The budget constraint facing the generation born at time $s \geq t$ is

$$
c_{y s}+\frac{c_{o s+1}}{1+r_{s+1}}=w_{s}(1-\ell y s)+\frac{w_{s+1}(1-\ell o s+1)}{1+r_{s+1}}-\left(T_{y s}+\frac{T_{o s+1}}{1+r_{s+1}}\right)
$$

The term in the large brackets on the right-hand side of $(3)$ is the present value of net taxes of the generation born at time s, i.e., its generational account.

Total net payments of the young and old at time $s \geq t$ equal government consumption spending Gs, i.e.,

$$
T_{y s}+T_{o s}=G_{s}
$$

Although (4) appears to ignore government borrowing, it is, in fact, a general formulation. As Kotlikoff (1993) shows, any government fiscal policy involving borrowing can be relabeled as one in which government debt is always zero.

We now consider changes in different generations' utilities arising from a policy reform introduced at time $t$. In so doing, we begin with the utility change of the elderly at time $t$ who were born in $t-1$.

5 To keep the analysis simple, we assume that the young and old receive the same wage per unit of labor supply at a point in time. 


$$
d U_{t-1}=\frac{\delta u}{\delta c_{o t}} d c_{o t}+\frac{\delta u}{\delta \ell_{o t}} d \ell_{o t}
$$

Differentiating (2) and using the first-order condition of the elderly at time $t$, which involve marginal after-tax prices, we get the normalized utility change

$$
\begin{aligned}
\frac{d v_{t-1}}{\lambda_{t-1}} & =\left(1+\tau_{o t}\right) d c_{o t}+w_{t}\left(1-\theta_{o t}\right) d l_{o t} \\
& =-d T_{o t}+\left[k_{t} d r_{t}+\left(1-\ell_{o t}\right) d w_{t}\right]+\left[\tau_{o t} d c_{o t}-w_{t} \theta_{o t} d l_{o t}\right],
\end{aligned}
$$

where $\lambda_{t-1}$ is the marginal utility of income of the elderly at time $t$ (who were born at $\mathrm{t}-1), \tau_{\text {ot }}$ is the marginal consumption tax rate facing the elderly at time $t, \theta_{\text {ot }}$ is the marginal tax on labor income facing the elderly at time $t$, and where we have used the fact that at time $t, k t$ is given, so dkt equals zero.

In (6), the utility change of the elderly is decomposed into three components: changes in their generational account (-dTot), changes in their factor incomes (the first bracketed term on the equation's right side), and changes in their tax payments due to changes in their economic behavior (the second bracketed term on the right-hand-side). The utility change of those born at time $s \geq t$ can be similarly decomposed. Differentiating equation (1) and using relevant first-order conditions leads to

(7) $\frac{\mathrm{dU}_{s}}{\lambda_{s}}=\left(1+\tau_{\mathrm{ys}}\right) \mathrm{dc}_{\mathrm{ys}}+w_{s}\left(1-\theta_{\mathrm{ys}}\right) \mathrm{d} \ell_{\mathrm{ys}}+\frac{\left(1+\tau_{o s+1}\right) \mathrm{dc} \mathrm{os}_{\mathrm{o}+1}+\mathrm{w}_{s+1}\left(1-\theta_{o s+1}\right) \mathrm{d} \ell_{o s+1}}{1+\mathrm{r}_{s+1}\left(1-\phi_{o s+1}\right)}$, where $\phi_{o s+1}$ is the marginal capital income tax faced by the elderly at time $s+1$. Combining (7) with the differential of (3) gives 
(8) $\frac{\mathrm{dU}_{s}}{\lambda_{s}}=-\left(\mathrm{dT}_{\mathrm{ys}}+\frac{\mathrm{dT} \mathrm{os}_{\mathrm{o}+1}}{1+\mathrm{r}_{s+1}}\right)+\left(\left(1-\ell_{\mathrm{ys}}\right) \mathrm{dw}_{s}+\frac{\left(1-\ell_{o s+1}\right) \mathrm{dw}_{s+1}+\mathrm{k}_{s+1} \mathrm{dr}_{s+1}}{1+\mathrm{r}_{s+1}}\right)$

$$
+\left(\begin{array}{c}
r_{y s} d c_{y s}-w_{s} \theta_{y s} d \ell_{y s}+\frac{\left[\tau_{o s+1}\left(1+r_{s+1}\right)+r_{s+1} \phi_{o s+1}\right]}{1+r_{s+1}\left(1-\phi_{o s+1}\right)} \frac{d c_{o s+1}}{1+r_{s+1}} \\
+\frac{\left[r_{s+1} \phi_{o s+1}\left(1+r_{s+1}\right) \theta_{o s+1}\right] w_{s+1}}{1+r_{s+1}\left(1-\phi_{o s+1}\right)} \frac{d \ell_{o s+1}}{1+r_{s+1}}
\end{array}\right) .
$$

In (8), the normalized utility change of generation $s \geq t$ consists of the same three components encountered in (6): the change in its generational account (the first right-hand-side term in large brackets), the change in factor income (the second right-hand-side term in large brackets), and the marginal change in tax revenue associated with a change in economic behavior (the third right-hand-side term in large brackets).

To determine the generations' changes in utility arising from a finite, rather than an infinitesimal, change in policy, one needs to integrate (6) and (8) over a dummy variable indicating the degree to which the policy reform is implemented. To be more precise, let $z$ run from 0 to 1 , where, for example, a value of $z$ equal to .5 means that the policy has been 50 percent implemented and a value of 1 means it has been fully implemented. The change in utility of generation $s$, for $s$ $\geq t-1, \Delta U s$, is given by

$$
\Delta \mathrm{U}_{s}-\int_{0}^{1} \frac{1}{\lambda} \frac{\delta \mathrm{U}_{s}}{\delta z} \mathrm{dz}
$$

Substituting from (6) and (8) for the integrand in (9) yields an expression for generations' utility change that has three pieces (three areas) corresponding to the 
integrals of the three terms on the right-hand sides of $(6)$ and $(8)$. These three areas are exactly analogous to the three areas in Figure 1 ; i.e., one reflects the change in tax revenues (in this case, changes in generational accounts), one reflects changes in factor incomes, and one reflects changes in tax avoidance.

To summarize this section, the changes in the utilities of all generations alive after a policy reform depends on more than just the changes in their generational accounts. Changes in generational accounts will not, except in special circumstances, provide a full accounting of the intergenerational incidence of fiscal reforms. Hence, the question is not whether generational accounting gets intergenerational incidence exactly right. It doesn't. Rather the question is how accurately it approximates true intergenerational incidence. This is the issue which we now explore with the AK Model.

\section{The Auerbach-Kotlikoff Model}

The AK model contains three sectors: households, firms, and government. The household sector consists of fifty-five overlapping generations, with the total population growing at a constant rate $\mathrm{n}$. Each adult agent lives for 55 years corresponding to ages 21 to 75 , and is concerned only with his own welfare, i.e., there is no bequest motive. Since all agents within a cohort are identical, economic opportunities differ only across cohorts. The model incorporates variable labor supply, including endogenous retirement. Preferences over current and future consumption and leisure are governed by the CES utility function

$$
\mathrm{U}=\frac{1}{1-\frac{1}{\gamma}} \sum_{\mathrm{a}-1}^{55}(1-\delta)^{1-\mathrm{a}}\left(\mathrm{c}_{\mathrm{a}}^{1-1 / \rho}+\beta \ell_{\mathrm{a}}^{1-1 / \rho}\right)^{\frac{1-1 / \gamma}{1-1 / \rho}}
$$


where $\delta$ is the "pure" rate of time preference, $\rho$ is the intratemporal elasticity of substitution between consumption and leisure at each age $a, \gamma$ as the intertemporal elasticity of substitution between consumption of different years, and $\beta$ is the leisure preference parameter. Since government spending does not enter into the utility function, changes in generations' utilities reflect only the incidence of the method of financing the spending.

Agents are assumed to have perfect foresight and experience realistic growth in their wages during their working years. This age-wage profile is separate from the general level of wages, the time-path of which is determined by the model. The model's production sector is characterized by perfectly competitive firms operating with a CES production function. The capital adjustment cost function depends on the level of investment at time $t$, It, the capital stock at time $t, K t$, and a coefficient $b$. It is given by

$$
\varphi\left(I_{t}, K_{t}\right)=.5 b \frac{I_{t}^{2}}{K_{t}} .
$$

The model incorporates income taxes, wage taxes, capital income taxes, and consumption taxes, all of which can be levied at proportional or progressive rates. The government's policy instruments include borrowing and a pay-as-you-go social security system. Government policy is constrained by the government's intertemporal budget constraint. As mentioned, this constraint requires that the present value of net taxes of current and future generations be sufficient to cover the present value of government consumption plus the value of existing government debt. The perfect foresight path of the AK Model is calculated using 
an iterative Gauss-Seidel algorithm. The algorithm assumes that the economy reaches its new steady state after 150 years. Table 1 displays our baseline parameter values.

Our simulations all start in year 1 from an initial steady state. They are quite similar to simulations reported in Auerbach and Kotlikoff (1987) and, consequently, we provide only a brief description of their impacts on macroeconomic variables. Our initial steady state features a 20 percent income tax which is used to finance public consumption, no government debt, and, except where indicated, no social security system. After solving for the transition path of the economy arising from a change in fiscal policy, we compute the difference between each generation's utility under the new policy and the initial steady-state level of utility, which represents the utility that the generation would have realized in the absence of the policy change.

Generations' changes in utility are divided by the post-policy reform marginal utilities of income. Changes in generational accounts and factor incomes are calculated using the post-policy-reform pre-tax interest rates to discount changes in net tax payments and factor income. ${ }^{6}$ In order to approximate ôUs in (9) and the integrals of the three right-hand-side components of $(6)$ and $(8)$, we simulated each policy reform in 5 steps. $^{7}$ Then we a) added together the resulting ratios of the change in utility divided by the marginal utility of income in that step, b) added together changes in the net tax payments and factor incomes discounted at the

6 The post-policy-reform pre-tax interest rate in year $s$ is the one that prevails in year $s$ in the transition to the new steady-state. results.

7 Using more than 5 steps in the numerical integration does not materially affect the 
interest rate in that step, and c) computed the change in tax avoidance as the difference between a) and b).

In presenting our calculated changes in each generation's utility, generational account, factor income, and tax avoidance, we scale these numbers (divide them) by the present value of the generation's expenditure on consumption and leisure, valued at the initial steady-state pre-tax prices.

\section{How Well Does Generational Accounting Track Changes in Generations' Utilities?}

This section considers two questions: First, how do changes in generational accounts compare with generations' actual utility changes? Second, are changes in generational accounts less accurate indicators of utility changes for young and future generations than they are for older generations because of the time needed in closed economies (without adjustment costs) for factor prices to change? We consider a variety of different policies, including increases in government spending financed by raising either income or consumption taxes, a partial shift in the tax structure from income to consumption taxation, a deficit-financed short-term tax cut, and an expansion of social security benefits. ${ }^{8}$

\section{Financing Additional Government Spending}

Our first simulation involves a permanent 20 percent rise in government spending financed by an increase in the rate of income taxation. As one would expect, this policy crowds out capital, lowers the real wage, and raises the real

${ }^{8}$ Although we report results for only a fixed set of parameters, we have run our policy experiments for a wide range of alternative parameters and found essentially the same results with respect to the ability of changes in generational accounts to track changes in welfare. 
interest rate. Table 2 reports initial steady-state (year 0) macro variables as well as the values of these variables along the economy's transition path. The capital stock, which initially equals 89.9, declines over time to 83.9. Associated with this decline is a 2 percent long-run decline in the wage and a 5 basis point increase in the interest rate. The income tax rate converges over time to 24.2 percent.

The first three columns of Table 3 decompose each generation's utility change into changes in its generational account (multiplied by minus 1), factor income, and tax avoidance. The total change in utility is given in the fourth column. Since the tax avoidance column is calculated at the difference between the sum of the first two columns and the fourth column, the tax avoidance figures will pick up the error in our method of approximating the integrals of the components of the change in utility.

In general, generational accounting does a very good job in this simulation in approximating generations' changes in utility. For the oldest generation, the change in generational account equals 91 percent of the total utility change. For 30-year-olds it equals 98 percent of the total, and for those born in year 0 , the year before the policy is enacted, it equals 78 percent of the total. For generations born after the transition begins, however, generational accounting does less well. For example, in the case of those born in the long run, the change in generational accounts equals 67 percent of the total change in utility.

The slow rate at which factor prices change in this simulation is the main reason that changes in generational accounts provide a worse approximation to utility changes of younger generations. The younger the generation, the more of its lifetime will be spent experiencing the lower wage, but higher interest rate, resulting from the policy change. For example, those born in the new steady state 
earn a 2 percent lower wage for their work effort and a 5 basis point higher interest rate on their savings.

Tables 4 and 5 report the results of a simulation that is identical to that underlying Tables 2 and 3 with the exception that the increase in government spending is financed using a proportional consumption tax. Unlike the income-taxfinanced increase in government spending, there is no crowding out of capital. Indeed, there is some minor crowding in. The reason is that the consumption tax falls more heavily on the initial elderly who have high propensities to consume. Since there is very little change in capital per work, there is little change in either the wage or interest rate. Hence, the factor income changes reported in Table 5 are quite small. The changes in generational accounts of particular generations are, however, significant. These changes account for most of the changes in generations' utility levels. The fraction of the utility change captured by the change in generational accounts ranges from 98 percent for the oldest cohort to 81 percent for cohorts born in the new steady state.

\section{Structural Tax Change}

Our next simulation, the macroeconomic and utility effects of which are reported in Tables 6 and 7, holds government spending fixed, but switches the tax structure from a 20 percent income tax to a 15 percent income tax plus a consumption tax whose rate is set to maintain the same revenues on an annual basis. In the first year of the transition the consumption tax is 6.4 percent and falls through time to 6.1 percent. In the long run, the capital stock increases (relative to its initial steady-state value) by 8.2 percent, the wage rises by 2.1 percent, and the pre-tax interest rate falls by 4 basis points. 
As Table 7 indicates, changes in generational accounts again do a very good job in capturing the general pattern of generation-specific utility changes. They do less well, for certain generations, in capturing the magnitude of those generations' utility changes. The changes in generational accounts are pretty close to the changes in utility for those initially over age 25. Unlike Tables 3 and 5, however, changes in generational accounts capture only about one third of the utility change for generations born in the long run.

The pattern of factor income changes in Table 7 deserves comment. In the first two years following the reform the substitution effects of a lower tax on labor income induces an increase in labor supply. This lowers the capital-labor ratio, reducing the real wage and raising the interest rate. The oldest generations benefit from this increase in the interest rate, which explains why the changes in factor incomes for those born 50 and 54 years before the reform are positive. Through time, the capital stock rises in response to the partial shifting of the burden of taxation from the young, with low propensities to consume, onto the elderly with high propensities to consume. ${ }^{9}$ This raises the wage. The income effects of this higher wage reduce labor supply, leaving labor supply in the new steady state at its initial steady-state value (at least to one decimal place). The increase, along the transition path, in the wage benefits initial future generations the most, because they work primarily or exclusively during years when the wage has reached or neared its peak. The counterpart of the rise in the wage is a decline in the interest rate. The loss to initial young and middle aged generations from the lower interest income they receive on their accumulated assets exceeds

9 Recall, that in the life-cycle model, propensities to consume rise with age in light of the shorter remaining lifespan. 
the gain to these generations of the rising wage. On net, they experience a decline in their factor incomes, whereas future generations experience, on net, an increase.

In this and the previous two simulations a pattern is emerging that merits comment, namely generational accounting is providing a lower bound estimate of the absolute change in welfare of those born in the long run. The reason is that policies which, over time, lower (raise) the economy's level of capital intensity are generally policies which redistribute from young and future generations (older) toward older (young and future) generations. ${ }^{10}$ Since a lower (higher) long-run degree of capital intensity means a lower (higher) long-run wage, the direct redistribution from those alive in the long run, which is captured by generational accounting, will understate the reduction (improvement) in welfare of those born in the long run.

\section{Debt Policy}

Tables 8 and 9 consider the effects of a deficit-financed temporary tax cut, specifically a three-year reduction from 20 percent to 16 percent in the rate of income taxation. After the three-year period, debt per capita is held fixed and the income tax rate is increased in order to cover government spending and interest on this level of debt. As Table 8 shows, the policy crowds-in capital in the short run, but crowds-out capital in the long run. The reason is the short-run increase in labor supply and earnings (some of which is saved) arising from the substitution

10 Income effects generally play a much more important role than do substitution effects in altering consumption and labor supply decisions, and policies that redistribute toward older generations are policies that redistribute toward generations with higher marginal propensites to consume. 
effects associated with the temporary tax cut; i.e., in the short run, when taxes are temporarily low, workers have an increased incentive to supply more labor. Once tax rates are raised, this incentive effect disappears. In the long run, the wage ends up .8 percent lower and the interest rate 2 basis points higher. These are small changes in relative factor returns. Accordingly, generationspecific changes in factor incomes reported in Table 9 are quite small.

There is, however, a substantial intergenerational redistribution from the policy, most of which is picked up by the changes in generational accounts. The policy is particularly advantageous to the oldest cohorts, because many are deceased after the tax rate is raised. Generational account changes are quite similar to generations' utility changes for all generations already born at the time of the policy change. For example, for those age 35 at the time of the policy change, the change in generational accounts equals 0.32 percent of remaining lifetime expenditures, whereas the change in utility is equivalent to a 0.35 percent reduction in expenditure. For generations born after the policy's enactment, generational account changes capture from 57 percent to 98 percent of the corresponding utility change. Again, since this policy ultimately crowds out capital by redistributing to early from later generations, generational accounting provides a lower bound for the decline in the welfare of long-run generations.

\section{Increasing Social Security Benefits}

In Tables 10 and 11 we simulate a 25 percent increase in social security benefits starting with a "pay-as-you-go" social security system with a 40 percent benefit-replacement rate. In the AK model, social security benefits are received at age 46 and continued until death at age 55. The actual benefits a generation 
receives are calculated from the average earnings over the first 45 years of their life span times the replacement rate, a parameter set by the government. Given the total sum of the benefits for a given year, the social security tax is calculated endogenously to meet social security benefit payments.

Table 10 shows that the policy crowds out the capital stock, reducing, in the process, the wage by 1.2 percent. The social security payroll tax, which is initially 6.5 percent, rises to over 8 percent. The income tax rate (not shown) rises from 20.0 percent to 20.4 percent. As in the previous simulations, the changes in capital intensity occur slowly. Consequently, the changes in generational accounts reported in Table 11 do an excellent job in capturing the utility of generations initially alive. They also capture over 60 percent of the utility changes of those born in the long run.

\section{Adjustment Costs}

Up to now we have assumed that the economy exhibits no adjustment costs, i.e., the installation of new capital is costless. As described by Hayashi (1982), increasing marginal costs of investment generate inframarginal rents to existing capital. The market valuation of the existing capital stock will therefore differ from its replacement cost. Tax policies that stimulate (depress) capital formation will immediately increase (reduce) the stock market value of existing capital. ${ }^{11}$ Since the elderly are the primary owners of existing capital, this capital gain (loss) will raise (lower) their wealth and welfare.

11 This abstracts from investment tax credits and other investment incentives that discriminate between new and old (existing) capital and, therefore, change the price of existing capital relative to new capital. As described in Auerbach, et. al. (1991), changes in Q that arise directly because of investment incentives are incorporated in the formation of generational accounts. 
In Tables 12-15 we repeat our structural tax reform and deficit-financed tax cut, but assume an adjustment cost parameter $b$ equal to 10 . This value for $b$ is reasonably large. It implies that 5 percent of steady state investment expenditure is spent on adjustment. It also produces a steady state value of $\mathbf{Q}$-- the ratio of the market value of capital to its replacement cost -- equal to $1.10 .^{12}$

Consider first the structural tax reform reported in Table 12. This reform raises the market value of capital in the short run by roughly 3 percent. Over time, $Q$ falls back to its initial steady-state value of 1.10 . Since older generations alive at the time of the tax reform can sell their capital at a 3 percent higher price, this capital gain (the value of which is included in the change in factor income column in Table 13) represents an offset to the reduction in utility of these generations associated with their being forced to absorb a larger tax burden. As Table 13 shows, the change in generational accounts overstates the reduction in welfare of initial older generations. Indeed, for the very oldest generation alive at the time of the reform, the true reduction in utility is roughly half of that suggested by the change in the generation's generational account. For younger generations and those born shortly after the reform, the change in generational accounts provides a fairly accurate assessment of the generations' ultimate change in utility. For those born in the long run, generational accounting captures about one third of the ultimate increase in utility.

In sum, in this simulation with adjustment costs, the changes in generational accounts overstate the losses to the initial elderly and understate the gains to the future young. But given the fact that the actual size and importance of adjustment costs is uncertain, the changes in generational accounts still represent a useful

$12 \mathrm{Q}$ equals 1 in the absence of adjustment costs. 
point of reference for considering the intergenerational welfare effects of this policy. Why? Because they provide, respectively, upper and lower bounds on the welfare losses and gains of those who are hurt and helped the most by the policy. Thus, they provide a "worse case" scenario which a prudent policy maker who is unsure of the extent of general equilibrium price adjustments can use in thinking through the costs and benefits of the policy reform.

Turn now to the deficit-financed tax cut policy, the results of which are presented in Tables 14 and 15. Due to the initial crowding in of capital in this policy, the price of existing capital initially rises. Consequently, the initial elderly experience a windfall gain, and their utility improvement exceeds the reduction in their generational accounts. Once the tax cut ends, the saving rate falls as does the price of capital. This capital loss produces a temporary decline in the interest rate. With the exception of those over 50, the changes in generational accounts accord quite closely with the changes in the utilities of those generations alive at the time the policy is initiated. As in previous simulations that involve long-run crowding-out of capital, the change in generational accounts provides a lower bound for the decline in welfare for those alive in the long run.

\section{Tax Progressivity}

Table 16 and 17 report the effects of switching from a 20 percent proportional income tax to a progressive one, where, as described in Auerbach and Kotlikoff (1987), the marginal tax rate is assumed to be liner in the tax base. Average tax rates in the year of the tax reform range from 19.1 percent for the

cohort age 1 , to 21.9 percent for the cohort age 25 , to 15.3 percent for the cohort age 55. The corresponding marginal tax rates are 23.2 percent for those 
initially age $1,28.8$ for those age 25 , and 15.7 percent for those age 55 . This age-pattern of average and marginal taxes reflects the life-cycle profile of income in which income is highest in middle age. The changes in generational accounts reflect, of course, not just the immediate changes in a generation's net tax payments, but future changes as well. As Table 17 shows, the switch to a progressive tax structure lowers the generational accounts of older and middleaged generations, raises the accounts of initial young generations, and lowers the accounts of generations born in the long run.

The policy change produces a very interesting set of dynamics with respect to capital intensity and factor payments. The increase in marginal tax rates produces an immediate and sustained decline in labor supply. The initial impact of less labor supply is a decline in capital intensity and a concomitant rise in the wage and decline in the interest rate. Over time, the decline in labor earnings plus the increase in consumption associated with the intergenerational redistribution toward the initial elderly crowds out investment, lowers the capital-labor ratio, and lowers the wage.

The non linear pattern of factor-price changes over the transition coupled with significant changes in tax avoidance in response to higher marginal tax rates means that changes in generational accounts do poorly in measuring the total changes in different generations' levels of utility. Indeed, in this case the sign of the change in generational accounts of those living in the long run is opposite to that of their utility change.

\section{Generational Accounting in a Small Open Economy}

We turn now to generational accounting in a small economy that faces perfectly elastic inflows and outflows of foreign capital. Let $r^{*}$ stand for the rate 
of return foreigners can earn abroad lafter foreign corporate income taxes, but before personal capital income taxes). Then since foreign investors must receive the same return (before personal capital income taxes) whether they invest at home or abroad, we have

$$
f_{s}^{\prime}\left(k_{s}\right)\left(1-\phi_{s}\right)-r^{*}
$$

where $f$ 's () is the time $s$ domestic marginal product of capital which depends on the capital-labor ratio $k s$ and $\phi_{S}$ is the time $s$ corporate income tax rate. ${ }^{13}$ According to (12), policy reforms that do not involve changes in corporate income taxation will leave pre-tax factor incomes unchanged. The reason is because the marginal products of capital as well as labor, which determine the pre-tax interest rate and wage, depend on the capital-labor ratio, which, according to (12), is pegged by $r^{*}$. Increases in the corporate tax rate, $\phi_{s}$, will raise the marginal product of capital and, consequently, lower the capital-labor ratio and, thus, the wage; i.e., a corporate income tax increase will be shifted onto workers. This suggests the need to modify generational accounting in small open economies by allocating corporate income taxes to generations in proportion to their labor income, rather than their assets.

To make this point more precise, suppose that the government of a twoperiod life-cycle small open economy uses only a corporate income tax to finance its spending. Now consider the changes in generations' utilities associated with an increase, beginning at time $t$, in the rate of corporate taxation. According to

13 We assume here that $\mathrm{f}^{\prime}()>0$ and $\mathrm{f}^{\prime \prime}()<0$. 
(6) and (8), the changes in utilities of the old at time $t$ and those born in $s \geq t$ are given by

$$
\frac{d U_{t-1}}{\lambda_{t-1}}=\left(1-\ell_{o t}\right) d w_{t}
$$

and

(14) $\frac{\mathrm{dU}_{s}}{\lambda_{s}}=\left(\left(1-\ell_{\mathrm{ys}}\right) \mathrm{dw}_{s}+\frac{\left(1-\ell{ }_{o s+1}\right) \mathrm{dw}_{s+1}}{1+\mathrm{r}^{*}}\right)$

since all other terms in (6) and (8) are zero. Now competition plus the assumption of constant returns to scale in production implies that $w s=f(k s)-f^{\prime}(k s) k s$, where $f(k s)$ is output per unit of labor input. Differentiating this expression as well as (12) and using the results to rewrite (13) and (14) leads to

$$
\frac{d U_{t-1}}{\lambda_{t-1}}=-\left(1-l_{o t}\right) \mathrm{dT}_{t}^{\mathrm{c}}+\left(1-\ell_{o t}\right) \mathrm{r}^{*} \frac{\phi_{t}}{\left(1-\phi_{t}\right)} \mathrm{dk}_{t}
$$

and

(14') $\frac{\mathrm{dU}_{s}}{\lambda_{s}}=-\left(\left(1-\ell_{\mathrm{ys}}\right) \mathrm{dT}_{s}^{\mathrm{c}}+\frac{\left(1-\ell_{\mathrm{os}+1}\right) \mathrm{dT}_{\mathrm{s}+1}^{\mathrm{c}}}{1+\mathrm{r}^{*}}\right)$

$$
+\left(1-\ell_{y s}\right) r^{*} \frac{\phi_{s}}{\left(1-\phi_{s}\right)} d k_{s}+\left(1-\ell_{o s+1}\right) r^{*} \frac{\phi_{s+1}}{\left(1-\phi_{s+1}\right)} \frac{d k_{s+1}}{1+r^{*}}
$$

where $T^{c} s$ is corporate tax revenue per unit of labor input. Equations (13') and $\left(14^{\prime}\right)$ indicate that apportioning changes in the corporate income tax to generations 
in proportion to their labor supply will leave each generation's change in its generational accounts equaling the change in its utility minus terms reflecting corporate tax avoidance arising from net capital outflows.

\section{Structural Tax Change}

Our first fiscal policy simulation in a small open economy involves a switch from income taxation to a combination of income and consumption taxation. Specifically we lower the tax on wage and corporate capital income from 20 percent to 15 percent and make up the loss in revenues by raising the consumption tax.

Table 18 documents the transition path for the economy under both personal and corporate taxation of capital income. In the case of personal capital income taxation, we assume that the government of the small open economy taxes the capital income received by its residents at the same rate regardless of whether that capital income is earned at home or abroad. In this case, (12) is replaced by

$$
\text { (12') } \quad f_{s}^{\prime}\left(k_{s}\right)=r^{*}
$$

which indicates that the pre-tax return to capital is pegged from abroad. This also means that the domestic capital-labor ratio and wage are pegged from abroad. In calculating changes in generational accounts with personal capital income taxation, policy-induced changes in personal capital income taxes are distributed to domestic residences in proportion to their holdings of assets.

Under corporate income taxation, the foreign country taxes its residents only on their capital income earned at home and does not credit taxes paid to other countries for capital income earned in those countries. Consequently, (12) holds, 
and an increase in the domestic corporate income tax leads to a reduction in capital intensity and a decline in the wage.

As Table 18 shows, the transition path of the economy is quite different depending on capital income is taxed at the personal or corporate level in our small open economy. Under personal capital income taxation, there are no changes in the wage or interest rate. However, there are some minor changes over time in the stock of capital and the supply of labor (although not in their ratio) as labor supply responds to the new tax environment. In contrast, under the corporate capital income tax, there is an immediate rise in the capital-labor ratio (as the decline $\Theta s$ in (12) implies) and a concomitant 2 percent rise in the wage.

Table 19 compares changes in generations' utility with their changes in generational accounts. Consider first the results based on personal capital income taxation. In this case, pre-tax factor incomes are unchanged by the change in tax structure and the changes in generational accounts do a very good job for existing generations in approximating actual changes in utility. For generations born in the long run, the change in generational accounts represents about two-thirds the change in utility.

Turn next to the results based on corporate income taxation. Again, changes in generational accounts do a very good job in capturing changes in generations' utilities when the change in corporate tax revenues is allocated by labor supply. For the sake of comparison, the table also shows the changes in generational accounts resulting from allocating changes in corporate taxes according to generations' holdings of assets. In this case, changes in generational accounts also provide a good approximation to changes in utilities for initial living generations, but provide a much poorer approximation for generations alive in the long run. 


\section{Debt Policy}

Table 20 shows the transition path resulting from running our previously discussed debt policy in a small open economy. As in the closed economy, the temporary reduction in tax rates leads to temporary increases in labor supply, labor earnings, saving, and the capital stock. But here we also have an immediate inflow of capital from abroad. Consequently, the short-run increase in the capital stock is greater in the open than in the closed economy (see Table 8). In the case of personal capital income taxation, there is, of course, no change in the wage associated with this debt policy. This is not true in the case of corporate income taxation. Indeed, with corporate income taxation, the wage rises in the very short run by more than 1 percent. This rise in the wage may be contrasted with the almost 1 percent short-run decline in the wage that arises under the closed economy debt policy. Table 21 compares generational account and utility changes under both personal and corporate capital income taxation. All in all, there is a very close correspondence in the table between generational account changes and utility changes.

\section{Increasing Social Security Benefits}

Our final simulation, the results of which are reported in Tables 22 and 23 , involves raising social security benefits by one quarter. The transition paths of the economy are similar under both personal and corporate capital income taxation. But unlike the closed economy case, in which the long-run capital stock was crowded out and the wage fell by 1.2 percent, there is no crowding out in these simulations and no long-run change in the wage. Changes in generational accounts again do very well in approximating changes in generations ${ }^{\prime}$ utilities. 


\section{Conclusion}

This paper shows how changes in generational accounts relate to the generational incidence of fiscal policy. Specifically, it uses the Auerbach-Kotlikoff Dynamic Life-Cycle Simulation Model to compare policy-induced changes in generational accounts with actual changes in generations' utilities. The paper considers changes in government spending, the tax structure, debt policy, social security benefit changes, and tax progressivity. It also considers a subset of these policies in an economy with capital adjustment costs and in a small open economy in which capital income is taxed either at the personal or corporate level.

In general, changes in generational accounts provide fairly good approximations to generations' actual changes in utilities. The approximations are better for living generations. They are worse for policies that involve significant changes in the degree of tax progressivity and for economies with sizable capitaladjustment costs.

Finally, generational accounting needs to be adjusted in the case of small open economies to take into account the fact that the incidence of corporate taxation is likely to fall on labor. The method of adjustment is simply to allocate changes in corporate tax revenues to generations in proportion to their labor supply. 


\section{References}

Auerbach, Alan J. and Laurence J. Kotlikoff, Dynamic Fiscal Policy, Cambridge, Cambridge University Press, 1987.

Auerbach, Alan J., Jagadeesh Gokhale, and Laurence J. Kotlikoff, "Generational Accounts: A Meaningful Alternative to Deficit Accounting," in D. Bradford, ed., Tax Policy and the Economy, vol. 5, Cambridge, MIT Press, 1991, pp. 55-110.

Auerbach, Alan J., Jagadeesh Gokhale, and Laurence J. Kotlikoff, "Generational Accounting: A Meaningful Way to Evaluate Generational Policy," The Journal of Economic Perspectives, 1994, pp. 73-94.

Auerbach, Alan J., Jagadeesh Gokhale, Laurence J. Kotlikoff, and Erling Steigum, Jr., "Generational Accounting in Norway: Is Norway Overconsuming Its Petroleum Wealth," The Ruth Pollak Working Paper Series on Economics no. 24, Boston University, Department of Economics, October 1993.

Boll, Stefan, Bernd Raffelhüschen, and Jan Walliser, "Social Security and Intergenerational Redistribution: A Generational Accounting Perspective", Public Choice, October 1994, pp. 79-100.

Cutler, David, "Tax Reform and the Stock Market -- An Asset Price Approach," American Economic Review, December 1988, pp. 1107-1117.

Franco, Daniele, Jagadeesh Gokhale, Luigi Guiso, Laurence J. Kotlikoff, and Nicola Sartor, "Generational Accounting -- The Case of Italy," in Saving and the Accumulation of Wealth, ed. by Albert Ando, Luigi Guiso, and Ignazio Visco, Cambridge, England: Cambridge University Press, 1994, pp.128-162.

Gokhale, Jagadeesh, Bernd Raffelhueschen, and Jan Walliser, "The Burden of German Unification: A Generational Accounting Approach," Federal Reserve Bank of Cleveland, working paper no. 9412, October 1994.

Hayashi, Fumio, "Tobin's Marginal q and Average q: A neoclassical Interpretation," Econometrica, vol. 50, 1982, 213-224.

Kotlikoff, Laurence J., Generational Accounting. The Free Press, 1992.

Kotlikoff, Laurence J., "From Deficit Delusion to the Fiscal Balance Rule -- Looking for a Sensible Way to Measure Fiscal Policy," The Journal of Economics, Seventh Supplement, 1993.

U.S. Office of Management and Budget, Budget of the United States Government Fiscal Year 1993, Washington DC: Government Printing Office, 1992.

U.S. Office of Management and Budget, Budget of the United States Government Fiscal Year 1994, Washington DC: Government Printing Office, 1993.

U.S. Office of Management and Budget, Budget of the United States Government Fiscal Year 1995, Washington DC: Government Printing Office., 1994. 
Table 1 Baseline Parameters

$\begin{array}{ll}\text { Population growth rate } & 0.01 \\ \text { Intertemporal elasticity of substitution }(\gamma) & 0.25 \\ \text { Intratemporal elasticity of substitution }(\rho) & 0.80 \\ \text { Pure rate of time preference } & 0.015 \\ \text { Leisure preference parameter } & 1.5 \\ \text { Elasticity of substitution between capital } & \\ \text { and labor } & 1.0\end{array}$




\section{Table 2}

\section{A 20 Percent, Income-Tax Financed, Increase in Government Spending: The Transition Path}

\begin{tabular}{|c|c|c|c|c|c|c|c|}
\hline Year & Capital & Labor & output & Wage & $\begin{array}{c}\text { Interest } \\
\text { Rate }\end{array}$ & $\begin{array}{c}\text { Income Tax } \\
\text { Rate }\end{array}$ & $\begin{array}{r}\text { Saving } \\
\text { Rate } \\
\end{array}$ \\
\hline 0 & 89.9 & 19.2 & 25.7 & 1.000 & .071 & .200 & .035 \\
\hline 1 & 89.9 & 19.2 & 25.6 & 1.001 & .071 & .241 & .020 \\
\hline 2 & 89.5 & 19.2 & 25.6 & 1.000 & .071 & .241 & .021 \\
\hline 3 & 89.1 & 19.2 & 25.6 & .988 & .072 & .241 & .021 \\
\hline 4 & 88.8 & 19.2 & 25.5 & .997 & .072 & 241 & .022 \\
\hline 5 & 88.4 & 19.2 & 25.5 & .996 & .072 & .241 & .023 \\
\hline 10 & 87.1 & 19.3 & 25.5 & .992 & .073 & .242 & .025 \\
\hline 20 & 85.4 & 19.3 & 25.4 & .986 & .074 & .242 & .029 \\
\hline 60 & 83.9 & 19.4 & 25.4 & .981 & .076 & .242 & .033 \\
\hline$\infty$ & 83.9 & 19.4 & 25.4 & .980 & .076 & .242 & .033 \\
\hline
\end{tabular}

\section{Table 3}

\section{A 20 Percent, Income-Tax Financed, Increase in Government Spending: Decomposing Generations' Utility Changes}

(changes, expressed as percent of remaining lifetime expenditure)

\begin{tabular}{lcccc}
$\begin{array}{l}\text { Generation's } \\
\text { Year of } \\
\text { Birth }\end{array}$ & $\begin{array}{c}\text { Generational } \\
\text { Account }\end{array}$ & $\begin{array}{c}\text { Factor } \\
\text { Income }\end{array}$ & $\begin{array}{c}\text { Tax } \\
\text { Avoidance }\end{array}$ & $\begin{array}{c}\text { Generation } \\
\text { Utility }\end{array}$ \\
\cline { 2 - 3 }-54 & -0.11 & & & \\
-54 & -0.23 & 0.01 & 0.00 & -0.12 \\
-50 & -0.57 & 0.08 & -0.11 & -0.33 \\
-45 & -0.96 & 0.15 & -0.19 & -0.68 \\
-40 & -1.31 & 0.21 & -0.20 & -1.01 \\
-35 & -1.61 & 0.24 & -0.23 & -1.33 \\
-30 & -1.86 & 0.24 & -0.29 & -1.63 \\
-25 & -2.04 & 0.21 & -0.33 & -1.91 \\
-20 & -2.17 & 0.15 & -0.36 & -2.16 \\
-15 & -2.23 & 0.08 & -0.42 & -2.38 \\
-10 & -2.25 & -0.01 & -0.46 & -2.72 \\
-5 & -2.22 & -0.10 & -0.50 & -2.82 \\
0 & -2.20 & -0.19 & -0.51 & -2.90 \\
5 & -2.17 & -0.28 & -0.53 & -2.98 \\
10 & -2.14 & -0.39 & -0.54 & -3.07 \\
20 & -2.12 & -0.48 & -0.54 & -3.14 \\
50 & -2.11 & -0.49 & -0.55 & -3.15 \\
$\infty$ & & & &
\end{tabular}


Table 4

A 20 Percent, Consumption-Tax Financed Increase in Government Spending: The Transition Patho

\begin{tabular}{|c|c|c|c|c|c|c|c|}
\hline Year & Capital & Labor & Output & Wage & $\begin{array}{c}\text { Interest } \\
\text { Rate }\end{array}$ & $\begin{array}{r}\text { Consumption } \\
\text { Tax Rate } \\
\end{array}$ & $\begin{array}{r}\text { Saving } \\
\text { Rate } \\
\end{array}$ \\
\hline 0 & 89.9 & 19.2 & 25.7 & 1.000 & .071 & .000 & .0 \\
\hline 1 & 89.9 & 19.4 & 25.8 & .998 & .072 & .053 & .0 \\
\hline 2 & 89.9 & 19.4 & 25.8 & .998 & .072 & .053 & .0 \\
\hline 3 & 89.9 & 19.4 & 25.8 & .998 & .072 & .053 & .0 \\
\hline 4 & 89.9 & 19.4 & 25.8 & .998 & .072 & .053 & .0 \\
\hline 5 & 89.9 & 19.4 & 25.8 & .998 & .072 & .053 & .0 \\
\hline 10 & 90.0 & 19.4 & 25.8 & .999 & .072 & .053 & .0 \\
\hline 20 & 90.1 & 19.4 & 25.8 & .989 & .072 & .053 & .03 \\
\hline 60 & 90.1 & 19.4 & 25.8 & .989 & .072 & .053 & .03 \\
\hline$\infty$ & 90.1 & 19.4 & 25.8 & .999 & .072 & .053 & .03 \\
\hline
\end{tabular}

${ }^{a}$ Simulation includes a 20 percent proportional income tax.

\section{Table 5}

\section{A 20 Percent, Consumption-tax Financed, Increase in Government Spending: Decomposing Generations' Utility Changes}

(changes, expressed as percent of remaining lifetime expenditure) Generation's

\begin{tabular}{|c|c|c|c|c|}
\hline $\begin{array}{l}\text { Year of } \\
\text { Birth }\end{array}$ & $\begin{array}{c}\begin{array}{c}\text { Generational } \\
\text { Account }\end{array} \\
\end{array}$ & $\begin{array}{l}\text { Factor } \\
\text { Income }\end{array}$ & $\begin{array}{c}\text { Tax } \\
\text { Avoidance }\end{array}$ & $\begin{array}{r}\text { Generatio } \\
\text { Utility }\end{array}$ \\
\hline-54 & -2.11 & 0.02 & -0.04 & -2.13 \\
\hline-50 & -2.03 & 0.04 & -0.06 & -2.05 \\
\hline-45 & -2.00 & 0.05 & -0.10 & -2.05 \\
\hline-40 & -1.97 & 0.06 & -0.15 & -2.06 \\
\hline-35 & -1.95 & 0.05 & -0.18 & -2.08 \\
\hline-30 & -1.93 & 0.04 & -0.22 & -2.11 \\
\hline-25 & -1.92 & 0.03 & -0.25 & -2.14 \\
\hline-20 & -1.90 & 0.01 & -0.29 & -2.18 \\
\hline-15 & -1.90 & 0.00 & -0.32 & -2.22 \\
\hline-10 & -1.90 & -0.02 & -0.34 & -2.26 \\
\hline-5 & -1.90 & -0.03 & -0.38 & -2.31 \\
\hline 0 & -1.91 & -0.04 & -0.41 & -2.36 \\
\hline 5 & -1.91 & -0.03 & -0.42 & -2.36 \\
\hline 10 & -1.91 & -0.03 & -0.42 & -2.36 \\
\hline 20 & -1.91 & -0.03 & -0.41 & -2.35 \\
\hline 50 & -1.91 & -0.02 & -0.42 & -2.35 \\
\hline$\infty$ & -1.91 & -0.02 & -0.42 & -2.35 \\
\hline
\end{tabular}




\section{Table 6 \\ Structural Tax Reform: The Transition Path}

\begin{tabular}{|c|c|c|c|c|c|c|c|}
\hline Year & Capital & Labor & Output & Wage & $\begin{array}{c}\text { Interest } \\
\text { Rate }\end{array}$ & $\begin{array}{c}\text { Consumption } \\
\text { Tax Rate } \\
\end{array}$ & $\begin{array}{r}\text { Saving } \\
\text { Rate } \\
\end{array}$ \\
\hline 0 & 89.9 & 19.2 & 25.7 & 1.000 & .071 & .000 & .035 \\
\hline 1 & 89.9 & 19.5 & 25.9 & .997 & .072 & .064 & .054 \\
\hline 2 & 90.4 & 19.5 & 25.9 & .998 & .072 & .064 & .053 \\
\hline 3 & 90.8 & 19.5 & 25.9 & 1.000 & .071 & .064 & .052 \\
\hline 4 & 91.3 & 19.4 & 26.0 & 1.001 & .071 & .064 & .051 \\
\hline 5 & 91.7 & 19.4 & 26.0 & 1.003 & .071 & .063 & .050 \\
\hline 10 & 93.4 & 19.4 & 26.0 & 1.008 & .070 & .062 & .047 \\
\hline 20 & 95.5 & 19.3 & 26.1 & 1.015 & .068 & .061 & .042 \\
\hline 60 & 97.2 & 19.2 & 26.1 & 1.021 & .067 & .061 & .037 \\
\hline$\infty$ & 97.3 & 19.2 & 26.1 & 1.021 & .067 & .061 & .03 \\
\hline
\end{tabular}

${ }^{\text {a }}$ Simulation entails an immediate and permanent reduction in a proportional income tax from 20 percent to 15 percent with the reduction in revenues made up through the introduction of a proportional consumption tax.

Table 7

Structural Tax Reform: Decomposing Generations' Utility Changes

(changes, expressed as percent of remaining lifetime expenditure)

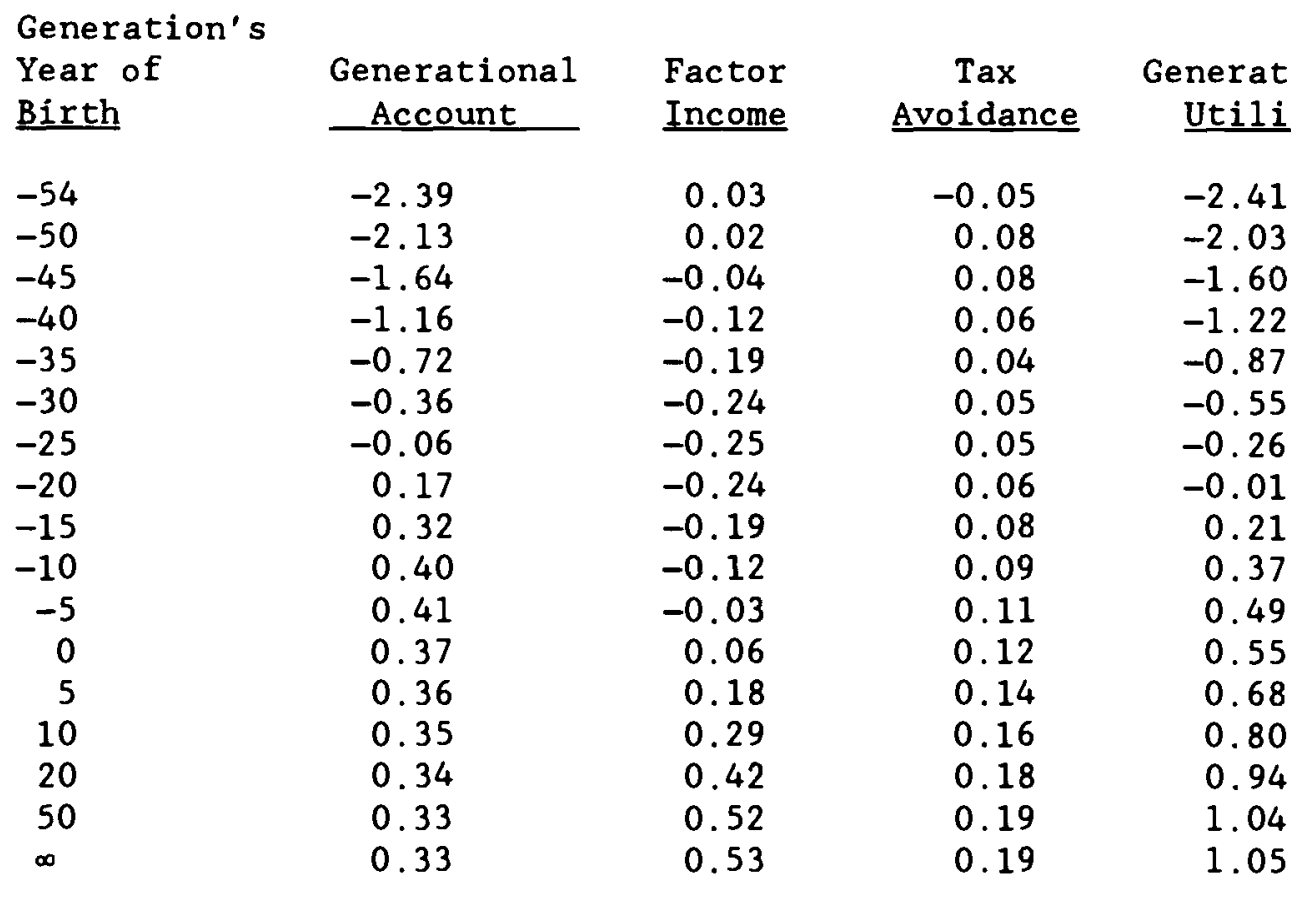


Table 8

Deficit-Financed Three-Year Income Tax Cut: The Transition Path

\begin{tabular}{|c|c|c|c|c|c|c|c|}
\hline Year & Capital & Labor & output & Wage & $\begin{array}{c}\text { Interest } \\
\text { Rate } \\
\end{array}$ & $\begin{array}{l}\text { Income } \\
\text { Tax Rate }\end{array}$ & $\begin{array}{r}\text { Saving } \\
\text { Rate } \\
\end{array}$ \\
\hline 0 & 89.9 & 19.2 & 25.7 & 1.000 & .071 & .200 & .035 \\
\hline 1 & 89.9 & 19.8 & 26.2 & .993 & .073 & .160 & .04 \\
\hline 2 & 90.1 & 19.8 & 26.2 & .994 & .073 & .160 & .04 \\
\hline 3 & 90.4 & 19.8 & 26.2 & .994 & .073 & .160 & .04 \\
\hline 4 & 90.6 & 19.1 & 25.5 & 1.004 & .070 & .206 & .02 \\
\hline 5 & 90.4 & 19.1 & 25.5 & 1.003 & .071 & .206 & .028 \\
\hline 10 & 89.6 & 19.1 & 25.5 & 1.001 & .071 & .207 & .030 \\
\hline 20 & 88.4 & 19.1 & 25.4 & .997 & .072 & .207 & .03 \\
\hline 60 & 86.8 & 19.2 & 25.4 & .992 & .073 & .207 & .034 \\
\hline$\infty$ & 86.8 & 19.2 & 25.4 & .992 & .073 & .208 & .03 \\
\hline
\end{tabular}

Table 9

\section{Deficit-Financed Three-Year Income Tax Cut Decomposing Generations' Utility Changes}

(changes, expressed as percent of remaining lifetime expenditure)

\begin{tabular}{lcccc}
$\begin{array}{l}\text { Generation's } \\
\text { Year of } \\
\text { Birth }\end{array}$ & $\begin{array}{c}\text { Generational } \\
\text { Account }\end{array}$ & $\begin{array}{c}\text { Factor } \\
\text { Income }\end{array}$ & $\begin{array}{c}\text { Tax } \\
\text { Avoidance }\end{array}$ & $\begin{array}{r}\text { Generation } \\
\text { Utilit }\end{array}$ \\
\cline { 2 - 2 }-54 & 0.10 & & & \\
-54 & 0.19 & 0.06 & 0.00 & 0.16 \\
-50 & 0.33 & 0.10 & 0.08 & 0.37 \\
-45 & 0.34 & 0.05 & 0.04 & 0.42 \\
-40 & 0.32 & 0.02 & 0.03 & 0.39 \\
-35 & 0.27 & 0.01 & 0.02 & 0.35 \\
-30 & 0.22 & 0.01 & 0.02 & 0.30 \\
-25 & 0.16 & 0.02 & 0.02 & 0.26 \\
-20 & 0.10 & 0.02 & 0.02 & 0.20 \\
-15 & 0.04 & 0.02 & 0.02 & 0.14 \\
-10 & -0.02 & 0.02 & 0.02 & 0.08 \\
-5 & -0.07 & 0.02 & 0.01 & 0.01 \\
0 & -0.40 & 0.01 & 0.01 & -0.05 \\
5 & -0.40 & 0.04 & -0.05 & -0.41 \\
10 & -0.39 & -0.01 & -0.06 & -0.47 \\
20 & -0.38 & -0.09 & -0.07 & -0.55 \\
50 & -0.38 & -0.20 & -0.08 & -0.66 \\
$\infty$ & -0.21 & -0.08 & -0.67 \\
\hline
\end{tabular}


Table 10

25 Percent Increase in Social Security Benefits:

The Transition Path

\begin{tabular}{|c|c|c|c|c|c|c|c|}
\hline Year & Capital & Labor & Output & Wage & $\begin{array}{c}\text { Interest } \\
\text { Rate }\end{array}$ & $\begin{array}{c}\text { Social Security } \\
\text { Tax Rate }\end{array}$ & $\begin{array}{r}\text { Saving } \\
\text { Rate }\end{array}$ \\
\hline 0 & 76.4 & 18.5 & 24.6 & 1.000 & 0.081 & 0.065 & 0.031 \\
\hline 1 & 76.4 & 18.1 & 24.3 & 1.005 & 0.079 & 0.082 & 0.014 \\
\hline 2 & 76.0 & 18.1 & 24.2 & 1.003 & 0.080 & 0.082 & 0.015 \\
\hline 3 & 75.6 & 18.1 & 24.2 & 1.002 & 0.080 & 0.082 & 0.016 \\
\hline 4 & 75.2 & 18.2 & 24.2 & 1.000 & 0.081 & 0.082 & 0.017 \\
\hline 5 & 74.9 & 18.2 & 24.2 & .999 & 0.081 & 0.082 & 0.018 \\
\hline 10 & 73.6 & 18.2 & 24.2 & .994 & 0.082 & 0.082 & 0.023 \\
\hline 20 & 72.6 & 18.3 & 24.1 & .990 & 0.083 & 0.081 & 0.028 \\
\hline 60 & 72.1 & 18.3 & 24.1 & .988 & 0.084 & 0.081 & 0.030 \\
\hline$\infty$ & 72.1 & 18.3 & 24.1 & .988 & 0.084 & 0.081 & 0.030 \\
\hline
\end{tabular}

Table 11

\section{Percent Increase in Social Security Benefits: Decomposing Generations' Utility Changes}

\begin{tabular}{|c|c|c|c|c|}
\hline $\begin{array}{l}\text { Year of } \\
\text { Birth }\end{array}$ & $\begin{array}{l}\text { Generational } \\
\text { Account }\end{array}$ & $\begin{array}{l}\text { Factor } \\
\text { Income }\end{array}$ & $\begin{array}{c}\text { Tax } \\
\text { Avoidance }\end{array}$ & $\begin{array}{c}\text { Generation's } \\
\text { Utility }\end{array}$ \\
\hline-54 & 3.56 & -0.03 & 0.07 & 3.60 \\
\hline-50 & 3.44 & -0.05 & 0.17 & 3.56 \\
\hline-45 & 3.84 & -0.01 & -0.23 & 3.60 \\
\hline-40 & 2.02 & 0.03 & -0.27 & 1.78 \\
\hline-35 & 1.07 & 0.08 & -0.23 & 0.92 \\
\hline-30 & 0.47 & 0.11 & -0.18 & 0.40 \\
\hline-25 & 0.05 & 0.14 & -0.16 & 0.03 \\
\hline-20 & -0.26 & 0.14 & -0.15 & -0.27 \\
\hline-15 & -0.50 & 0.12 & -0.14 & -0.52 \\
\hline-10 & -0.69 & 0.08 & -0.13 & -0.74 \\
\hline-5 & -0.83 & 0.03 & -0.12 & -0.92 \\
\hline 0 & -0.92 & -0.04 & -0.12 & -1.08 \\
\hline 5 & -0.88 & -0.15 & -0.13 & -1.16 \\
\hline 10 & -0.84 & -0.23 & -0.15 & -1.22 \\
\hline 20 & -0.81 & -0.30 & -0.15 & -1.26 \\
\hline 50 & -0.80 & -0.33 & -0.16 & -1.29 \\
\hline$\infty$ & -0.80 & -0.33 & -0.16 & -1.29 \\
\hline
\end{tabular}


Table 12

Structural Tax Reform With Capital Adjustment Costs: The Transition Path

\begin{tabular}{lccccccccc} 
Year & Capital & Labor & Output & Wage & $\begin{array}{c}\text { Interest } \\
\text { Rate }\end{array}$ & Q & $\begin{array}{c}\text { Consumption } \\
\text { Tax Rate }\end{array}$ & $\begin{array}{c}\text { Saving } \\
\text { Rate }\end{array}$ \\
0 & 81.9 & 19.2 & 25.6 & 1.000 & 0.072 & 1.100 & 0.000 & 0.032 \\
1 & 81.9 & 19.5 & 25.8 & 0.997 & 0.097 & 1.100 & 0.046 & 0.040 \\
2 & 82.2 & 19.4 & 25.7 & 0.999 & 0.072 & 1.127 & 0.063 & 0.041 \\
3 & 82.4 & 19.3 & 25.7 & 1.000 & 0.069 & 1.130 & 0.065 & 0.041 \\
4 & 82.6 & 19.3 & 25.7 & 1.001 & 0.069 & 1.129 & 0.065 & 0.041 \\
5 & 82.9 & 19.3 & 25.7 & 1.002 & 0.069 & 1.128 & 0.065 & 0.041 \\
10 & 83.9 & 19.3 & 25.8 & 1.005 & 0.069 & 1.123 & 0.064 & 0.040 \\
20 & 85.4 & 19.3 & 25.9 & 1.010 & 0.068 & 1.115 & 0.063 & 0.038 \\
60 & 88.0 & 19.2 & 26.0 & 1.019 & 0.067 & 1.103 & 0.061 & 0.035 \\
$\infty$ & 88.7 & 19.2 & 26.1 & 1.021 & 0.067 & 1.100 & 0.061 & 0.034 \\
\hline
\end{tabular}

\section{Table 13}

\section{Structural Tax Reform with Adjustment Costs: Decomposing Generations' Utility Changes}

(changes expressed as percent of remaining lifetime expenditure)

\begin{tabular}{|c|c|c|c|c|}
\hline $\begin{array}{l}\text { Generation's } \\
\text { Year of } \\
\text { Birth }\end{array}$ & $\begin{array}{l}\text { Generational } \\
\text { Account }\end{array}$ & $\begin{array}{l}\text { Factor } \\
\text { Income }\end{array}$ & $\begin{array}{c}\text { Tax } \\
\text { Avoidance }\end{array}$ & $\begin{array}{c}\text { Generati } \\
\text { Utilit }\end{array}$ \\
\hline-54 & -1.89 & 1.02 & -0.02 & -0.89 \\
\hline-50 & -2.12 & 0.89 & 0.03 & -1.20 \\
\hline-45 & -1.69 & 0.60 & 0.05 & -1.04 \\
\hline-40 & -1.21 & 0.33 & 0.04 & -0.84 \\
\hline-35 & -0.77 & 0.11 & 0.03 & -0.63 \\
\hline-30 & -0.39 & -0.07 & 0.03 & -0.43 \\
\hline-25 & -0.07 & -0.19 & 0.02 & -0.24 \\
\hline-20 & 0.17 & -0.26 & 0.03 & -0.06 \\
\hline-15 & 0.34 & -0.28 & 0.03 & 0.09 \\
\hline-10 & 0.43 & -0.26 & 0.05 & 0.22 \\
\hline-5 & 0.45 & -0.20 & 0.06 & 0.31 \\
\hline 0 & 0.40 & -0.11 & 0.08 & 0.37 \\
\hline 5 & 0.36 & -0.01 & 0.08 & 0.43 \\
\hline 10 & 0.36 & 0.08 & 0.10 & 0.54 \\
\hline 20 & 0.35 & 0.23 & 0.13 & 0.71 \\
\hline 50 & 0.34 & 0.43 & 0.18 & 0.95 \\
\hline$\infty$ & 0.33 & 0.53 & 0.20 & 1.06 \\
\hline
\end{tabular}


Table 14

Deficit-Financed Three-Year Income Tax Cut with Adjustment Costs: The Transition Path

\begin{tabular}{|c|c|c|c|c|c|c|c|c|}
\hline Year & Capital & Labor & Output & Wage & $\begin{array}{c}\text { Interest } \\
\text { Rate }\end{array}$ & 0 & $\begin{array}{c}\text { Income } \\
\text { Tax Rate }\end{array}$ & $\begin{array}{r}\text { Saving } \\
\text { Rate } \\
\end{array}$ \\
\hline 0 & 81.9 & 19.2 & 25.6 & 1.000 & 0.072 & 1.100 & 0.200 & 0.0 \\
\hline 1 & 81.9 & 19.7 & 26.1 & 0.994 & 0.087 & 1.100 & 0.160 & 0.0 \\
\hline 2 & 82.1 & 19.7 & 26.1 & 0.994 & 0.071 & 1.115 & 0.160 & 0.0 \\
\hline 3 & 82.2 & 19.7 & 26.1 & 0.994 & 0.071 & 1.114 & 0.160 & 0.0 \\
\hline 4 & 82.3 & 18.7 & 25.0 & 1.008 & 0.033 & 1.113 & 0.237 & 0.0 \\
\hline 5 & 82.1 & 19.3 & 25.7 & 0.999 & 0.096 & 1.073 & 0.192 & 0.0 \\
\hline 10 & 81.7 & 19.1 & 25.5 & 1.001 & 0.071 & 1.092 & 0.206 & 0.0 \\
\hline 20 & 81.1 & 19.1 & 25.4 & 0.999 & 0.072 & 1.093 & 0.206 & 0.0 \\
\hline 60 & 79.7 & 19.2 & 25.4 & 0.994 & 0.073 & 1.098 & 0.207 & 0.0 \\
\hline$\infty$ & 79.2 & 19.2 & 25.3 & 0.992 & 0.073 & 1.100 & 0.207 & 0.03 \\
\hline
\end{tabular}

\section{Table 15}

\section{Deficit-Financed Three-Year Income Tax Cut with Adjustment Costs: Decomposing Generations' Utility Changes}

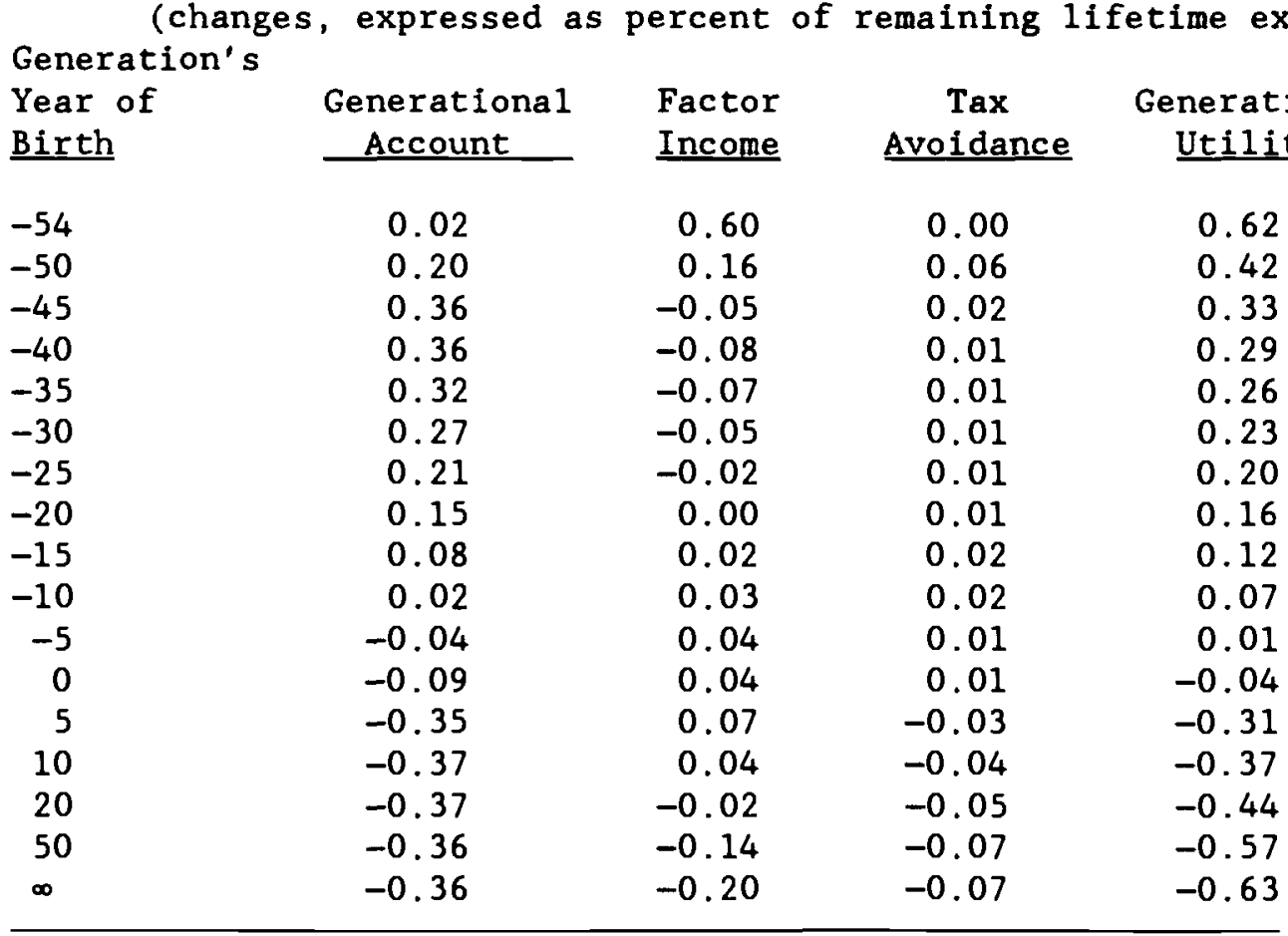


Table 16

\section{Increasing Tax Progressivity: The Transition Path}

\begin{tabular}{lcccccc} 
Year & Capital & Labor & Output & Wage & $\begin{array}{c}\text { Interest } \\
\text { Rate }\end{array}$ & $\begin{array}{c}\text { Saving } \\
\text { Rate }\end{array}$ \\
0 & 89.9 & 19.2 & 25.7 & 1.000 & 0.071 & 0.035 \\
1 & 89.9 & 18.3 & 24.7 & 1.013 & 0.069 & 0.014 \\
2 & 89.3 & 18.3 & 24.7 & 1.011 & 0.069 & 0.014 \\
3 & 88.8 & 18.3 & 24.6 & 1.010 & 0.069 & 0.015 \\
4 & 88.3 & 18.3 & 24.6 & 1.008 & 0.070 & 0.016 \\
5 & 87.8 & 18.3 & 24.6 & 1.006 & 0.070 & 0.016 \\
10 & 85.7 & 18.4 & 24.5 & 0.999 & 0.072 & 0.020 \\
20 & 82.9 & 18.5 & 24.4 & 0.990 & 0.074 & 0.026 \\
60 & 80.8 & 18.6 & 24.4 & 0.982 & 0.075 & 0.033 \\
$\infty$ & 80.7 & 18.6 & 24.4 & 0.982 & 0.075 & 0.033 \\
\hline
\end{tabular}

Table 17

Increasing Tax Progressivity:

Decomposing Generations' Utility Changes

(changes expressed as percent of remaining lifetime expenditure)

Generation's

\begin{tabular}{lcccc}
$\begin{array}{l}\text { Year of } \\
\text { Birth }\end{array}$ & $\begin{array}{c}\text { Generational } \\
\text { Account }\end{array}$ & $\begin{array}{c}\text { Factor } \\
\text { Income }\end{array}$ & $\begin{array}{c}\text { Tax } \\
\text { Avoidance }\end{array}$ & $\begin{array}{c}\text { Generation's } \\
\text { Utility }\end{array}$ \\
\cline { 2 - 2 }-54 & 0.15 & -0.11 & 0.00 & 0.04 \\
-50 & 0.28 & -0.23 & 0.08 & 0.13 \\
-45 & 0.46 & -0.25 & -0.02 & 0.19 \\
-40 & 0.45 & -0.19 & -0.16 & 0.10 \\
-35 & 0.31 & -0.10 & -0.31 & -0.10 \\
-30 & 0.11 & 0.00 & -0.47 & -0.36 \\
-25 & -0.09 & 0.09 & -0.60 & -0.60 \\
-20 & -0.22 & 0.16 & -0.72 & -0.78 \\
-15 & -0.28 & 0.21 & -0.78 & -0.85 \\
-10 & -0.25 & 0.22 & -0.79 & -0.82 \\
-5 & -0.15 & 0.20 & -0.75 & -0.70 \\
0 & -0.01 & 0.16 & -0.68 & -0.53 \\
5 & 0.01 & 0.01 & -0.69 & -0.67 \\
10 & 0.04 & -0.14 & -0.70 & -0.80 \\
20 & 0.08 & -0.31 & -0.73 & -0.96 \\
50 & 0.10 & -0.43 & -0.74 & -1.07 \\
$\infty$ & 0.10 & -0.45 & -0.74 & -1.09 \\
\hline
\end{tabular}


Table 18

Generational Accounting In A Small Open Economy Structural Tax Changea: The Transition Path

\begin{tabular}{|c|c|c|c|c|c|c|c|c|c|}
\hline \multirow[b]{2}{*}{ Year } & \multicolumn{4}{|c|}{ Personal Capital Income Tax } & \multicolumn{5}{|c|}{ Corporate Capital Income Tax } \\
\hline & Capital & Labor & Output & $\begin{array}{l}\text { Saving } \\
\text { Rate }\end{array}$ & Capital & Labor & Output & Wage & $\begin{array}{l}\text { Saving } \\
\text { Rate }\end{array}$ \\
\hline$\overline{0}$ & $\overline{89.9}$ & $\overline{19.2}$ & 25.7 & $\overline{0.035}$ & 89.9 & 19.2 & 25.7 & 1.000 & 0.035 \\
\hline 1 & 91.6 & 19.6 & 26.2 & 0.064 & 99.7 & 19.7 & 26.8 & 1.020 & 0.052 \\
\hline 2 & 91.5 & 19.6 & 26.1 & 0.059 & 99.6 & 19.7 & 26.8 & 1.020 & 0.052 \\
\hline 3 & 91.3 & 19.5 & 26.1 & 0.058 & 99.4 & 19.6 & 26.7 & 1.020 & 0.051 \\
\hline 4 & 91.1 & 19.5 & 26.0 & 0.057 & 99.3 & 19.6 & 26.7 & 1.020 & 0.050 \\
\hline 5 & 91.0 & 19.5 & 26.0 & 0.057 & 99.2 & 19.6 & 26.7 & 1.020 & 0.050 \\
\hline 10 & 90.2 & 19.3 & 25.8 & 0.053 & 98.6 & 19.5 & 26.5 & 1.020 & 0.047 \\
\hline 20 & 89.2 & 19.1 & 25.5 & 0.048 & 97.8 & 19.3 & 26.3 & 1.020 & 0.043 \\
\hline 60 & 88.0 & 18.9 & 25.1 & 0.039 & 97.1 & 19.2 & 26.1 & 1.020 & 0.037 \\
\hline$\infty$ & 88.0 & 18.9 & 25.1 & 0.039 & 97.1 & 19.2 & 26.1 & 1.020 & 0.037 \\
\hline
\end{tabular}

${ }^{a}$ Simulation entails an immediate and permanent reduction in proportional wage income and corporate income taxes from 20 to 15 percent with the reduction in revenues made up through the introduction of a proportional consumption tax.

\section{Table 19 Generational Accounting In A Small Open Economy, Structural Tax Change Decomposing Generations' Utility Changes}

\begin{tabular}{|c|c|c|c|c|c|c|c|}
\hline \multirow{3}{*}{$\begin{array}{l}\text { Year } \\
\text { of } \\
\text { Birth }\end{array}$} & \multicolumn{2}{|c|}{$\begin{array}{c}\text { Personal Capital } \\
\text { Income } \mathrm{Tax}\end{array}$} & \multicolumn{5}{|c|}{ Generational Account } \\
\hline & \multicolumn{2}{|c|}{ Generational } & \multirow{2}{*}{$\begin{array}{l}\text { Factor } \\
\text { Income }\end{array}$} & \multicolumn{2}{|c|}{ allocated by } & & \multirow[b]{2}{*}{ Utility } \\
\hline & Account & Utility & & Ass & & & \\
\hline-54 & -2.35 & -2.40 & 0.00 & -2.10 & -2.22 & -2 & \\
\hline-50 & -2.11 & -2.02 & 0.03 & -2.00 & -2.31 & -2 . & \\
\hline-45 & -1.62 & -1.54 & 0.12 & -1.61 & -2.06 & -1 & \\
\hline-40 & -1.14 & -1.09 & 0.23 & -1.19 & -1.71 & -1 & \\
\hline-35 & -0.71 & -0.67 & 0.35 & -0.80 & -1.32 & -1 & \\
\hline-30 & -0.35 & -0.30 & 0.46 & -0.46 & -0.92 & -0 . & \\
\hline-25 & -0.05 & 0.01 & 0.57 & -0.17 & -0.54 & -0 . & \\
\hline-20 & 0.17 & 0.26 & 0.68 & 0.06 & -0.18 & 0 . & \\
\hline-15 & 0.31 & 0.44 & 0.77 & 0.23 & 0.13 & 0 . & \\
\hline-10 & 0.39 & 0.54 & 0.85 & 0.34 & 0.38 & 0 . & \\
\hline-5 & 0.39 & 0.57 & 0.90 & 0.38 & 0.56 & 0 . & \\
\hline 0 & 0.34 & 0.54 & 0.93 & 0.36 & 0.65 & 0 . & \\
\hline 5 & 0.35 & 0.56 & 0.93 & 0.34 & 0.64 & 0 . & \\
\hline 10 & 0.36 & 0.57 & 0.93 & 0.32 & 0.64 & 0 . & \\
\hline 20 & 0.37 & 0.58 & 0.93 & 0.30 & 0.63 & 0. & \\
\hline 50 & 0.37 & 0.59 & 0.93 & 0.29 & 0.62 & 0 . & \\
\hline$\infty$ & 0.37 & 0.59 & 0.93 & 0.29 & 0.62 & 0 . & \\
\hline
\end{tabular}


Table 20

Generational Accounting In A Small Open Economy Deficit-Financed Three-Year Income Tax Cut: The Transition Path

\begin{tabular}{|c|c|c|c|c|c|c|c|c|c|}
\hline \multirow[b]{3}{*}{ Year } & \multicolumn{4}{|c|}{ Personal Capital Income Tax } & \multicolumn{5}{|c|}{ Corporate Capital Income Tax } \\
\hline & & & & Saving & & & & & Savir \\
\hline & Capital & Labor & Output & Rate & Capital & Labor & Output & Wage & Rate \\
\hline 0 & 89.9 & 19.2 & 25.7 & $\overline{0.035}$ & 89.9 & 19.2 & 25.7 & 1.000 & 0.035 \\
\hline 1 & 93.0 & 19.9 & 26.6 & 0 . & 98.3 & 20.0 & 27.0 & 1. & 56 \\
\hline 2 & 92.9 & 19.9 & 26.5 & 0 . & 98.3 & 20.0 & 27.0 & 1. & 57 \\
\hline 3 & 92.8 & 19.9 & 26.5 & +6 & 98.3 & 20.0 & 27.0 & 1.013 & 59 \\
\hline 4 & 88.8 & 19.0 & 25.3 & 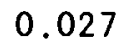 & 87.8 & 19.0 & 25.3 & 0.997 & 0.027 \\
\hline 5 & 88.8 & 19.0 & 25.4 & 0 & 87.9 & 19.0 & 25.3 & 0.997 & 0.028 \\
\hline 10 & 89.0 & 19.1 & 25.4 & 0. & 88.1 & 19.1 & 25.3 & 0.998 & 0.028 \\
\hline 20 & 89.4 & 19.1 & 25.5 & 0.029 & 88.6 & 19.1 & 25.4 & 0.998 & 0.029 \\
\hline 60 & 90.3 & 19.3 & 25.8 & 34 & 89.5 & 19.3 & 25.6 & 0.999 & 0.03 \\
\hline & 90.2 & 19.3 & 25.8 & 0.034 & 89.4 & 19.3 & 25.6 & 0.999 & 0.032 \\
\hline
\end{tabular}

Table 21

Generational Accounting In A Small Open Economy

Deficit-Financed Three-Year Income Tax Cut Decomposing Generations' Utility Changes

\begin{tabular}{|c|c|c|c|c|}
\hline \multirow{2}{*}{$\begin{array}{l}\text { Year of } \\
\text { Birth }\end{array}$} & \multicolumn{2}{|c|}{$\begin{array}{c}\text { Personal Capital } \\
\text { Income Tax } \\
\end{array}$} & \multicolumn{2}{|c|}{$\begin{array}{l}\text { Corporate Capital } \\
\text { Income Tax }\end{array}$} \\
\hline & Gen.ACC. & Utility & Gen, $A C C$. & Utilit \\
\hline-54 & 0.11 & 0.11 & 0.00 & 0.00 \\
\hline-50 & 0.19 & 0.29 & -0.10 & 0.07 \\
\hline-45 & 0.33 & 0.37 & 0.12 & 0.20 \\
\hline-40 & 0.34 & 0.37 & 0.21 & 0.24 \\
\hline-35 & 0.31 & 0.33 & 0.24 & 0.25 \\
\hline-30 & 0.26 & 0.28 & 0.25 & 0.25 \\
\hline-25 & 0.21 & 0.23 & 0.24 & 0.23 \\
\hline-20 & 0.15 & 0.17 & 0.21 & 0.20 \\
\hline-15 & 0.09 & 0.10 & 0.18 & 0.16 \\
\hline-10 & 0.03 & 0.04 & 0.13 & 0.11 \\
\hline-5 & -0.02 & -0.02 & 0.08 & 0.06 \\
\hline 0 & -0.07 & -0.08 & 0.03 & 0.01 \\
\hline 5 & -0.37 & -0.47 & -0.36 & -0.40 \\
\hline 10 & -0.38 & -0.48 & -0.34 & -0.37 \\
\hline 20 & -0.38 & -0.48 & -0.30 & -0.32 \\
\hline 50 & -0.38 & -0.48 & -0.25 & -0.26 \\
\hline 150 & -0.38 & -0.48 & -0.26 & -0.27 \\
\hline
\end{tabular}


Table 22

Generational Accounting In A Small Open Economy 25 Percent Increase in Social Security Benefits: The Transition Path

\begin{tabular}{|c|c|c|c|c|c|c|c|c|c|}
\hline \multirow[b]{3}{*}{ Year } & \multicolumn{4}{|c|}{ Personal Capital Income Tax } & \multicolumn{5}{|c|}{ Corporate Capital Income Tax } \\
\hline & & & & Saving & & & & & Saving \\
\hline & Capital & Labor & Output & Rate & Capital & Labor & Output & Wage & Rate \\
\hline 0 & 76.4 & $\overline{18.5}$ & 24.6 & $0 . \overline{031}$ & 76.4 & $\overline{18.5}$ & 24.6 & 1.000 & 0.031 \\
\hline 1 & 74.2 & 17.9 & 23.9 & 0.008 & 72.6 & 17.8 & 23.6 & .997 & 0.002 \\
\hline 2 & 74.4 & 18.0 & 24.0 & 0.009 & 73.0 & 17.9 & 23.7 & .997 & 0.004 \\
\hline 3 & 74.6 & 18.0 & 24.0 & 0.010 & 73.4 & 17.9 & 23.9 & .997 & 0.006 \\
\hline 4 & 74.8 & 18.1 & 24.1 & 0.011 & 73.8 & 18.0 & 24.0 & .998 & 0.008 \\
\hline 5 & 74.9 & 18.1 & 24.1 & 0.012 & 74.1 & 18.1 & 24.0 & .998 & 0.010 \\
\hline 10 & 75.5 & 18.3 & 24.3 & 0.017 & 75.3 & 18.3 & 24.3 & .999 & 0.018 \\
\hline 20 & 76.2 & 18.4 & 24.6 & 0.024 & 76.4 & 18.5 & 24.6 & 1.000 & 0.026 \\
\hline 60 & 76.6 & 18.5 & 24.7 & 0.028 & 76.4 & 18.5 & 24.6 & 1.000 & 0.029 \\
\hline$\infty$ & 76.6 & 18.5 & 24.7 & 0.029 & 76.4 & 18.5 & 24.6 & 1.000 & 0.029 \\
\hline
\end{tabular}

Table 23

Generational Accounting In A Small Open Economy

25 Percent Increase in Social Security Benefits

Decomposing Generations' Utility Changes

\begin{tabular}{|c|c|c|c|c|}
\hline \multirow{2}{*}{$\begin{array}{l}\text { Year of } \\
\text { Birth }\end{array}$} & \multicolumn{2}{|c|}{$\begin{array}{l}\text { Personal Capital } \\
\text { Income Tax }\end{array}$} & \multicolumn{2}{|c|}{$\begin{array}{c}\text { Corporate Capital } \\
\text { Income } \mathrm{Tax}\end{array}$} \\
\hline & Gen Acc. & Utility & Gen, AcC, & Utility \\
\hline-54 & 3.56 & 3.62 & 3.56 & 3.63 \\
\hline-50 & 3.42 & 3.60 & 3.45 & 3.52 \\
\hline-45 & 3.75 & 3.50 & 3.71 & 3.27 \\
\hline-40 & 2.04 & 1.74 & 2.05 & 1.60 \\
\hline-35 & 1.10 & 0.86 & 1.13 & 0.78 \\
\hline-30 & 0.49 & 0.29 & 0.55 & 0.28 \\
\hline-25 & 0.07 & -0.12 & 0.14 & -0.07 \\
\hline-20 & -0.25 & -0.43 & -0.17 & -0.32 \\
\hline-15 & -0.49 & -0.67 & -0.41 & -0.51 \\
\hline-10 & -0.68 & -0.87 & -0.58 & -0.66 \\
\hline-5 & -0.81 & -1.01 & -0.70 & -0.75 \\
\hline 0 & -0.90 & -1.12 & -0.78 & -0.81 \\
\hline 5 & -0.88 & -1.09 & -0.70 & -0.71 \\
\hline 10 & -0.86 & -1.07 & -0.63 & -0.64 \\
\hline 20 & -0.86 & -1.07 & -0.60 & -0.59 \\
\hline 50 & -0.88 & -1.10 & -0.64 & -0.64 \\
\hline 150 & -0.88 & -1.09 & -0.64 & -0.63 \\
\hline
\end{tabular}

